\title{
Total cost of ownership in pallet pools management
}

\author{
Mariusz Sowa ${ }^{1, a}$ \\ ${ }^{1}$ Department of Logistics, Faculty of management and Economics of Services, University of Szczecin, Cukrowa 8 Street, 71-004 Szczecin, \\ Poland
}

\begin{abstract}
Every loading pallet, regardless of the type, in order to be considered safe during the operation phase, must meet certain formal requirements already at the implementation stage. The loading pallet marketed has a certain life span. The life of the pallet depends on many factors. First of all, they are related to the physical and economic aging of the product. Physical aging consists in the fact that the materials from which the products have been made lose their properties, and the economic ones are the result of the emergence of new, better products on the market, better meeting the specific needs of recipients. The operational life of the cargo pallet also depends on the organization of the transport process, branch and means of transport as well as the date of its completion. The concept of calculating the total cost of ownership of a reusable loading pallet in logistic processes, proposed in the article, allows to determine the total costs of its operation. It is based on the idea of Total Cost of Ownership (TCO), which includes total acquisition costs, installation costs, maintenance costs and costs of its disposal over particular time
\end{abstract}

\section{Introduction}

A pallet is most often a wooden structure that is used for transporting goods / loads, but also finds use as a rigid base on which larger-sized goods are laid and in smaller packages, thus facilitating logistic operations. The pallets are designed by manufacturers so that they can be easily lifted using forklifts and other logistics equipment. Currently, the pallet market is striving for a greater variety of pallets, both in terms of dimensions, materials from which they are made, and due to the type of their use. Pallets should be considered as an important element of the comprehensive logistics process. Optimally selected and used pallets contribute to both lowering the costs of freight flows and to increasing the quality of logistics processes.

A pallet is a supporting transport and storage equipment, adapted to motorized facilities and for stacking loads. Pallet load units created on the bas is of various types of pallets can be used in rotation taking place in numerous actors of chains of supply. To be considered safe in the operating phase each pallet, regardless of its type, has to meet particular formal requirements as early as at the workmanship phase. However, the operating phase of a product can be defined as its total duration on the market, which starts when the product is released on the market until it is withdrawn from it. Therefore, a pallet released on the market has service life. This, above all, is related to economic and physical ageing of the product. Whereas physical ageing consists in materials used to manufacture the product that lose its properties, economic ageing results from the introduction of new, better products which are better

\footnotetext{
a Corresponding author: mariuszsowa.ps@poczta.fm
}

targeted to the needs of consumers. Service life of a pallet depends on the way transporting process is organized, mode and means of transport and time when it was produced as well.

Possession of ownership obviously involves purchase costs, but ownership also involves costs associated with the installation, implementation, use, updating and maintenance of the same resources. These costs after purchase can be significant. Therefore, for many types of ass ets total cost of ownership analysis of TCO, finds a significant difference between the purchase price and the total life-cycle costs. The difference can be very large when the ownership period covers a longer period. As a result, the TCO analysis sends an important message to corporate buyers, capital control groups and asset managers. Total Cost of Ownership (TCO) is an analys is aimed at discovering all life-cycle costs resulting from having certain types of assets. As a result, the Englishlanguage literature TCO is often called life-cycle cost analysis.

\section{2 . The life cycle of the pallet load}

The physical aspect of the life cycle of a loading pallet can be understood as a material based life cycle, which is based on the transformation of materials and energy. Is a sequence of activities such as: acquisition and purchase of raw materials, material processing, production (assembly) of pallets, use and distribution of pallets, recovery and utilization of pallets. In the life cycle understood in this way, the loading pallet begins its "life" 
from the moment of obtaining the raw material necessary for its production.

The assessment of the actual lifetime of the pallet is possible due to the analysis of the conditions of its operation in particular branches of transport. However, the logistics life cycle of individual pallets, since its introduction until the withdrawal from the market, in addition to the time factor should be analysed sales volume and the relationship between the quality of the product and the requirements of consumers, as well as issues of efficiency of its use in supply chains. In order to ass ess the actual duration of the operational phase of the loading pallet in particular branches of transport, it is necessary to analyse the type of transhipment devices used, the means of transport used, atmospheric conditions, duration of displacement and the mode of its operation. The type of material raw materials, their composition, proportions, methods and techniques of production and the intended purpose of the product have an impact on its life cycle [1]. However, shortening the product life time is not always the result of a decrease in its durability or an earlier loss of its technical and utility properties. The introduction of new or modernized products may also contribute to this phenomenon. However, this may lead to an increase in the ecological hazard caused by the operation of products, the emergence of post-consumer and production waste as well as the increased acquisition of primary raw materials and energy. Acquisition of primary raw materials, their processing and production of final products cause negative changes in ecosystems, change living conditions and disturb the balance of the ecosystem. Process es occurring in production systems are the source of waste with various concentrations and harmfulness.

The total cost of ownership highlights the difference between the purchase price and the long-term cost. This analysis has been at the center of interest since the mid1980s due to expenses related to the purchase of IT hardware and software. Managers then discovered that hardware and software support could cost 5 to 8 times more than the purchase price.

When the differences between total cost of ownership and price were at the forefront, companies began to use these calculations for a wide range of investment decisions, including: buildings, vehicles, production equipment and information technology infrastructure. The concept of the total cost of ownership of a reusable flat load pallet allows to determine the total costs of its use and to indicate activities that increase its operational life. It is based on the idea of Total Cost of Ownership (TCO), which includes the total cost of obtaining, putting into use (installation), use, maintenance and finally getting rid of the product over a specified period of time. The proposed TCO concept contributes to the recognition of re latively all costs associated with the entire lifetime of a reusable loading pallet. It also allows you to better understand and account for future costs that are invisible when you buy a pallet. The cost of buying a pallet is relatively simple to estimate. However, the calculation of the costs of the pallet's design, its as sembly, maintenance, modernization and finally withdrawal from use is much more difficult. Helpful in this situation may be to use the model of the total cost of ownership. TCO plays an important role in making informed financial decisions regarding the purchase of a given product or service. In the case of loading pallets, it takes into account not only the purchase price of the pallet, but also the anticipated costs related to its life cycle [2], which include, among others: costs related to the design of the pallet, the purchase cost of the pallet, operating costs of the pallet, maintenance costs pallets. From the factors mentioned above, it follows that the total cost of owning a pallet is not only the cost of buying it, but also the costs associated with its maintenance. The pallet's TCO model is used to assess both current and forecast costs. It includes direct costs as well as indirect costs (hidden) that are revealed during the operation phase. The TCO model can be divided into individual groups of costs related to the life cycle of the pallet, as shown in Figure 1.

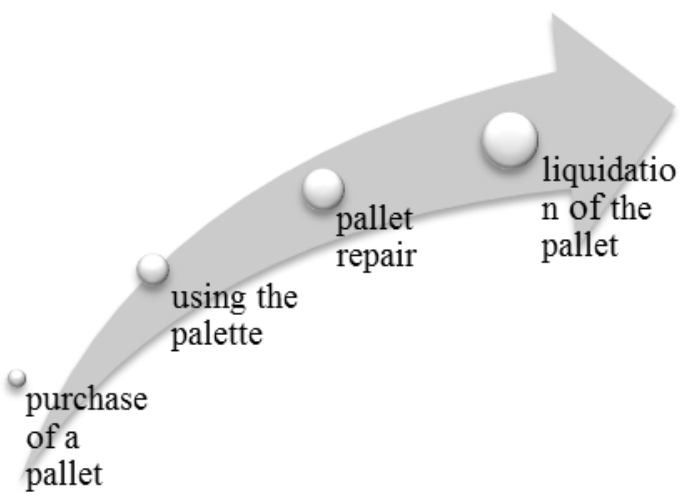

Figu re 1. Simplified life cycle of the loading pallet Source: Own study

On the basis of this life cycle loading pallets can be distinguished among others cost group:

- costs related to the purchase of a pallet, which include, among others [3]:

- direct costs related to production, such as, among others:

- design costs (costs of market research, costs of prototyping, testing costs),

- costs of using direct materials (wood), components,

- costs of purchased materials (nails, brackets),

- direct labor costs,

- costs of energy and fuel consumption,

- costs of processing a foreign raw material, if it is not carried out by a production company. Wooden elements, pallets, dunnage materials made of wood must be subjected to a series of processes, such as: heat treatment, fumigation, certification and marking according to the ISPM15 standard,

- costs of remuneration, insurance and other benefits of production workers and production supervision (apprenticeship allowances, bonuses, holiday pay),

- indirect costs associated with the production, such as [4]:

- faculty costs:

- fixed - costs remaining unchanged despite fluctuations in production volume, e.g. 
depreciation of machines, devices, buildings and structures, non-life insurance, costs of heating, lighting, maintenance, etc.,

- variables - costs depending on the size of production, e.g. drive energy of machines and devices, maintenance and repair costs of machinery and equipment, consumption of materials for traffic, etc.,

- board costs[5]:

- administrative and economic costs, for example: wages of management and administration employees along with overheads,

- business travel costs of management and adminis tration employees,

- office costs, such as office supplies, telecommunications charges, costs of data archiving, accounting services,

- training costs for management and administration staff,

- cost taxes, such as a property tax on the board building

- general production costs [6]:

- maintenance costs for buildings and general premises as well as management,

- costs of the usage license,

- costs related to the use of the pallet, related to the current operation of the pallet, including[7]:

acquisition cost,

storage cost,

transport costs,

servicing costs,

costs related to obtaining certificates,

costs of pallet exchange materials,

repair costs of the pallet,

- costs related to the liquidation of the pallet, which include:

transport costs,

disassembly costs,

disposalcosts.

\section{The total cost of ownership of the loading pallet}

Obviously, ownership of property is associated with purchase costs, but owning also has costs associated with installing, implementing, using, updating and maintain ing the same resources. These costs can be significant after purchase. Therefore, for many types of assets, the analys is of the total cost of ownership of a TCO finds a significant difference between the purchase price and the total life cycle costs. The difference can be very large if the ownership covers a longer period. As a result, the TCO analysis sends an important message to corporate buyers, capital control groups and asset managers. Total Cost of Ownership (TCO) is an analysis aimed at uncovering all life-cycle costs arising from having specific types of assets. As a result, in English literature on the subject, TCO is often called life-cycle cost analys is. Total Cost of Ownership (TCO) is a term that is intended to determine the structure of costs associated with the operation of assets in a given enterprise. Refers to assets (investments) with long-term economic consequences. TCO is a method, often understood as a model, a concept that allows the decision-maker not only to determine the direct costs that are reflected in accounting documents (invoices), but also to estimate indirect (hidden) costs calculated according to individual division keys used in a given business entity. It can be used to estimate the costs that an investor will have to bear during the operation of a given asset (e.g. car, garage, warehouse, IT system, pallet), but also allows (at the stage of making a decision on purchasing or manufacturing) to determine what will be loss of market value (for examp le, after a given useful life of the as set. It is a concept of total costs of use, which presents a comprehensive approach to the costs of a given technology, e.g. IT or a given investment (e.g. purchase of pallets) in a given time period. The TCO model also includes a methodology for planning and conducting continuous cost rationalization. TCO contributes to knowing relatively all costs that are associated with the entire lifetime of the pallet. It also allows you to better understand and account for future costs that are invisible when you buy the pallet. The cost of purchasing a pallet as a carrier is relatively simple to estimate. However, calculating the costs of pallet design, assembly, maintenance, modernization and finally decommissioning is much more difficult. The total cost of ownership model may be helpful in this situation. TCO plays an important role in making informed financial decisions regarding the purchase of a given product or service. In the case of pallets, it not only takes into account the purchase price of the pallet, but also the anticipated costs related to its life cycle.

The total cost of ownership of the loading pallet consists of the sum of: purchase cost, maintenance cost, operating cost and withdrawal cost. Therefore, the TCO formula of a reusable flat pallet takes into account, in addition to the purchase price of a pallet, service or solution, also the expected costs related to the life of the pallet, which include servicing, repairs, storage, etc. This concept is presented in the figure 2 .

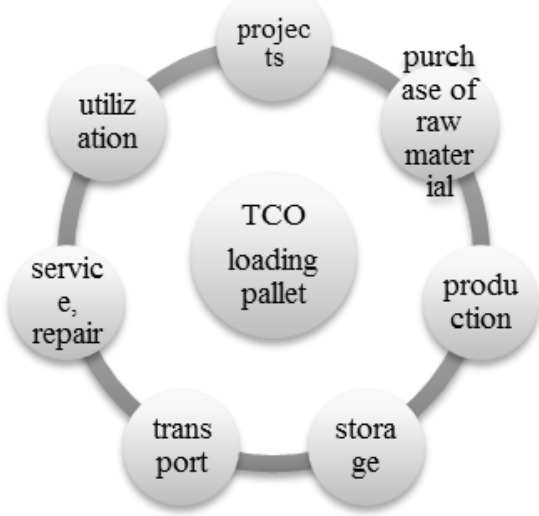

Figu re 2. General assumptions of the TCO model of the loading pallet Source: Own study.

The factors presented in the figure show that the total cost of owning a pallet is not only the cost of purchasing it, but also the costs associated with maintaining it. The TCO model of the pallet is used to evaluate both current 
and projected costs. It includes direct costs as well as indirect (hidden) costs that are revealed during the exploitation phase.

TCO model shows all the costs that are incurred throughout the life cycle of the pallet, since her shopping until getting rid of. If you add the costs of storage, repair costs or the cost of disposal to the basic price of the pallet, it may turn out that a much more advantageous solution for the company will be to use the palette pool system (open pool palettes) than definitely to buy it [8]. In taking this decision will serve analysis of the total cost of ownership, thanks to which the company is able to provide for additional costs as sociated with the purchase of the pallet.

At the stage of making decisions regarding the purchase of pallets by the company, the criterion that is taken into account is the most common and only the price. Entrepreneurs rarely include other expenses related to owning a pallet pool, such as e.g. repair costs. However, to have a full picture of it, it becomes justified to use the TCO model, because it indicates all the costs that are incurred throughout the entire life cycle of the pallet, from the moment of its purchase until disposal. If we add storage costs, repair costs or disposal costs to the basic price of the pallet, it may turn out that using a pallet rental system (open pallet system) will be a much more beneficial solution than definitely buying it. This decision will certainly be based on an analysis of the total cost of ownership, thanks to which the company is able to predict the additional costs associated with purchasing a pallet.

\section{Conclusion}

Total Cost of Ownership (TCO) is a term used to determine the structure of costs related to the operation of assets in a given enterprise. It applies to assets (investments) on the long-term economic consequences. TCO is often understood as a model, a concept that allows the decision maker not only to determine direct costs, which are reflected in accounting documents (invoices), but also to estimate indirect (hidden) costs calculated according to individual division keys used in a given economic unit. It includes the total cost of obtaining, putting into use (installation), use, maintenance and finally getting rid of the product over a specified period of time. The proposed TCO concept of the loading pallet contributes to the recognition of all the costs associated with the entire life of the pallet. It also allows you to better understand and account for future costs that are invisible when you buy a pallet. The pallet's TCO model is used to assess both current and forecast costs. It includes direct costs as well as indirect costs (hidden) that are revealed during the operation phase.
This concept will allow enterprises to obtain a useful instrument for determining the total operating costs of a pallet that is widely used in the course of trade. It will also allow to indicate the area of activities increasing its operational life, which will result in their better use, cost savings, but also reduce the negative impact of their logistics activities on the natural environment.

\section{Acknowledgments}

The article is financed within the framework of the program of the Min ister of Science and Higher Education under the name "Regional Excellence In itiative" in the years 2019 - 2022; project number 001/RID/2018/19; the amount of financing PLN 10,684,000.00

\section{References}

1. Rosa G Perenc J Ostrowska I 2016 Marketing przyszłości Od ujęcia tradycyjnego do nowoczesnego Wydawnictwo C. H. Beck Warszawa pp.171-173

2. Selech J Kurczewski P 2010 Metoda szacowania kosztu cyklu życia (LCC) $i$ jej zastosowanie $w$ dziedzinie budowy $i$ eksploatacji obiektów technicznych Inżynieria i aparatura chemiczna $\mathrm{nr} 5$ pp.79-83

3. Sobańska I 2009 Podstawy rachunku kosztów $i$ wyników W Rachunek kosztów Podejście operacyjne i strategiczne Wydawnictwo C.H. Beck Wars zawa pp. $80-87$

4. Sobańska I 2006 Rachunek kosztów i rachunkowość zarzadcza Najnowsze tendencje, procedury $i$ ich zastosowanie $w$ przedsiębiorstwach Wydawnictwo C.H.Beck Warszawa pp.119-127

5. Szczypa P 2017 Zasady rachunkowości Teoria przykładyzadania $\mathrm{CeDeWu}$, Warszawa pp.152-153

6. Okoń J 2014 Zastosowanie rachunku kosztów działań $w$ zarzadzaniu portfelem produktów W Studia ekonomic zne Kierunki harmonizacji polskiej rachunkowości $\mathrm{z}$ międzynarodowymi standardami sprawozdawczości finansowej Seria Zeszyty Naukowe Wydziałowe Uniwersytetu Ekonomicznego w Katowicach Katowice pp.45-49

7. Jarugowa A Malc W Sawicki K 2012 Rachunek kosztów PWE Warszawa 1983 pp.44, cyt. za Szczypa P Rachunkowość zarzadcza. Klucz do sukcesu CEDEWU Warszawa pp.20-21

8. Jedliński M 2016 Koncepcja dynamicznej efektywności palety $w$ analizie społecznych kosztów $i$ korzyści $w$ fazie użytkowania palety drewnianej wielokrotnego uzytku [III Konferencja Paletowa PKN EPAL, Józefów 